\title{
PENERAPAN MODEL PEMBELAJARAN KOOPERATIF BERBANTUAN PERMAINAN BINGO UNTUK MENINGKATKAN PENGUASAAN HURUF HIRAGANA SISWA KELAS X IBB 1 SMA NEGERI 1 SUKASADA TAHUN AJARAN 2018/2019
}

\author{
N.D.D.Jaya ${ }^{1}$ K.E.K.Adnyani² D.M.S.Mardani ${ }^{3}$ \\ Program Studi Pendidikan Bahasa Jepang, Jurusan Bahasa Asing, Fakultas Bahasa dan Seni Universitas \\ Pendidikan Ganesha, Singaraja, Indonesia \\ e-mail : danu.darma.jaya@undiksha.ac.id \\ krishna.adnyani@undiksha.ac.id desak.mardani@undiksha.ac.id
}

\begin{abstract}
ABSTRAK
Penelitian ini bertujuan untuk (1) meningkatkan penguasaan huruf hiragana setelah diterapkannya model pembelajaran kooperatif berbantuan permainan bingo siswa kelas XIBB 1 SMA N 1 Sukasada tahun ajaran 2018/2019 dan (2) mendeskripsikan respons siswa terhadap penerapan model pembelajaran kooperatif berbantuan permainan bingo untuk meningkatkan penguasaan huruf hiragana siswa. Jenis penelitian ini adalah penelitian tindakan kelas yang dilaksanakan dalam dua siklus. Subjek pada penelitian ini adalah siswa kelas X IBB 1 SMA N 1 Sukasada sebanyak 24 orang siswa pada semester genap tahun ajaran 2018/2019. Metode pengumpulan data yang digunakan pada penelitian ini adalah observasi, tes, kuesioner, dan wawancara. Data yang telah terkumpul dianalisis secara deskriptif kualitatif dan deskriptif kuantitatif. Hasil penelitian menunjukkan bahwa (1) penerapan model pembelajaran kooperatif berbantuan permainan bingo mampu meningkatkan penguasaan huruf hiragana siswa kelas X IBB 1 SMA N 1 Sukasada tahun ajaran 2018/2019. Hal tersebut ditunjukkan dengan adanya peningkatan persentase ketuntasan klasikal yaitu, pada pretest ketuntasan klasikal sebesar $20,83 \%$. Pada siklus I terjadi peningkatan sebesar $62,50 \%$. Pada siklus II meningkat menjadi $100 \%$. (2) Respons siswa positif terhadap penerapan model pembelajaran kooperatif berbantuan permainan bingo.
\end{abstract}

Kata kunci: model pembelajaran kooperatif, permainan bingo, huruf hiragana

\section{要旨}

本研究の目的は、(1) 2018/2019 年度第一スカサダ国立高等学校言語クラスの 10 年生における平仮 名を身につけるためのビンゴゲームを通じる協同学習方法の利用、(2) 平仮名を身につけるためのビンゴ ゲームを通じる協同学習方法の利用に対する学習者の反応を明らかにすることを目的としている。調査 は二周期に教室実践活動調査である。研究の対象は 2018/2019 年度第一スカサダ国立高等学校言語クラ スの一年生の 24 名である。データ収集方法は観察、テスト、アンケート、及びインタビューである。 そのデータを定量的および定性的な記述法により分析した結果、(1) 2018/2019 年度第一スカサダ国立高 等学校言語クラスの一年生がビンゴゲームを通じる協同学習方法平仮名を身につけることが出来た。そ れは合格率の向上による示された。事前テストの合格率が $20.83 \%$ 、一回目のサイクルの合格率が 62.50\%、二回目のサイクルの合格率が 100\%に達した。(2) 平仮名を身につけるためのビンゴゲームを 通じる協同学習方法の利用に対する学習者の反応がポジティブである。

キーワード : 協同学習方法、ビンゴゲーム、平仮名 


\section{PENDAHULUAN}

Bahasa Jepang merupakan salah satu mata pelajaran yang dipelajari di SMA di kabupaten Buleleng. Penting adanya mempelajari bahasa Jepang karena selain mampu menguasai budayanya juga mampu mempelajari bahasanya dengan baik. Dalam bahasa Jepang terdapat 3 huruf yaitu, huruf Hiragana, huruf Katakana dan huruf Kanji. Masing-masing huruf tersebut memiliki karakteristik yang berbeda-beda, salah satunya adalah huruf Hiragana.

Huruf Hiragana biasanya digunakan untuk menulis kosakata asli dari Jepang. Huruf Hiragana mempunyai tingkat kesulitan tersendiri seperti bentuk huruf, goresan dan lain-lain. Dalam penulisan huruf Hiragana terdapat 4 buah goresan yaitu tomemasu, haraimasu, hanemasu dan yoko haraimasu. Selain itu kekeliruan yang sering terjadi ketika mempelajari huruf Hiragana adalah adanya kemiripan huruf seperti huruf あ dengan お, き dengan さ,は dengan ほ dan た dengan に. Hal ini yang menyebabkan siswa kesulitan dalam menulis huruf Hiragana dengan baik.

Berdasarkan hasil observasi di sekolah SMA N 1 Sukasada menyatakan kemampuan siswa dalam menguasai dan memahami huruf hiragana masih kurang. Pada hasil wawancara yang telah dilakukan bahwa siswa-siswi di kelas X IBB 1 yang sangat mengalami masalah dalam memahami huruf hiragana. Hasil wawancara menyatakan bahwa $80 \%$ siswa tidak bisa menulis huruf hiragana dengan baik dan hanya $20 \%$ yang bisa menulis huruf hiragana dengan baik. Berdasarkan hasil pengamatan di kelas karakteristik siswa cenderung lebih senang bermain dengan teman sebangku.

Upaya yang harus dilakukan dalam mengatasi kendala pembelajaran di kelas dengan menerapkan model pembelajaran yang tepat dengan lebih bervariasi. Namun di SMA N 1 Sukasada masih saja menerapkan metode pembelajaran ceramah ataupun metode drill. Hal ini menyebabkan siswa di kelas menjadi bosan dan cenderung tidak bisa mengikuti pembelajaran dengan baik. Peran guru juga menjadi tidak optimal dalam mengkondisikan kelas karena harus memerhatikan siswa yang tidak memerhatikan guru dengan baik.

Model pembelajaran adalah suatu perencanaan atau pola yang digunakan sebagai pedoman dalam merencanakan pembelajaran di kelas atau pembelajaran tutorial. (Trianto, 2010). Dengan menggunakan model pembelajaran guru akan lebih terstruktur dalam hal mengajar. Guru akan dituntut untuk mempersiapkan segala sesuatu yang berhubungan dengan proses pembelajaran. Kondisi siswa yang cenderung pasif dan tidak fokus dalam setiap pembelajaran menimbulkan proses belajar yang tidak kondusif. Pemilihan model pembelajaran yang tepat juga akan membantu proses pembelajaran menjadi lebih menarik dan menyenangkan.

Menurut Suprijono (2009: 54) model pembelajaran kooperatif adalah konsep yang lebih luas meliputi semua jenis kerja kelompok termasuk bentuk-bentuk yang lebih dipimpin oleh guru atau diarahkan oleh guru. Hal ini sangat sejalan dengan karakteristik siswa yang sangat senang mengerjakan sesuatu dengan cara berkelompok. Dalam pembelajaran kooperatif siswa akan sering bertanya dengan anggota kelompok sehingga kemampuan individu siswa dalam mengungkapkan sesuatu akan terasah dan siswa akan menjadi terbiasa dalam berbicara didepan. Pembagian kelompok belajar bersifat heterogen yaitu siswa yang cenderung pintar tidak akan dikelompokan oleh siswa yang pintar melainkan dengan siswa yang memiliki kemampuan dibawah rata-rata. Adapun kelebihan dari model pembelajaran kooperatif salah satunya membantu anak untuk respect pada orang lain dan menyadari akan segala keterbatasannya serta menerima segala perbedaan. Hal ini sangat tepat dengan kondisi di kelas X IBB 1 yaitu siswa yang lebih pintar tidak sombong dengan kepintaran yang dimiliki melainkan saling membantu temanya jika terdapat kesulitan dalam menjawab soal.

Kendala yang lain dari siswa adalah siswa masih lemah dalam mengingat bentuk huruf dan goresan huruf hiragana. Terbukti dari hasil pre-test yang telah diberikan $85 \%$ siswa masih kebingungan menulis huruf-huruf yang memiliki kemiripan bentuk. Dalam penelitian ini teknik yang digunakan adalah mnemonic. Mnemonic menurut Anari,dkk (2015) adalah suatu teknik yang belajar yang mengandalkan ingatan atau memory seseorang dalam memudahkan 
mengaitkan suatu objek atau informasi-informasi yang masuk ke dalam otak manusia. Dengan berbantuan mnemonic dalam belajar bahasa Jepang, siswa diharapkan menjadi lebih mudah dalam mengingat huruf hiragana.

Dalam proses pembelajaran tidak cukup hanya mengandalkan metode atau model pembelajaran saja namun perlu mengkolaborasikan antara model pembelajaran dengan media pendukung yang lainnya seperti permainan, teka-teki silang dan masih banyak lagi yang lainnya. Dengan menggunakan media permainan pada pembelajaran bahasa Jepang akan memudahkan siswa untuk mengerti dan pembelajaran di kelas tidak lagi membosankan. Karakteristik siswa di kelas X IBB 1 sangat senang bercanda dan bermain dengan teman sebangku jadi tidak menutup kemungkinan dengan mengkolaborasikan model pembelajaran dengan media permainan akan lebih memudahkan siswa belajar huruf hiragana di kelas.

Menggunakan media permainan dalam menunjang pembelajaran di kelas merupakan salah satu cara agar semangat siswa belajar semakin meningkat. Dalam hal ini, permainan bingo dipilih sebagai media pembelajaran huruf hiragana. Permainan Bingo menurut Yulaekha (2016) adalah permainan yang menggunakan media kartu yang berisi poin-poin materi pelajaran yang mempunyai aturan tertentu, dan disusun secara vertikal, horizontal maupun diagonal sedangkan Bingo adalah teriakan para pemain sebagai tanda kemenangan. Adapun kelebihan dari permainan bingo adalah siswa menjadi lebih bersemangat dalam mengikuti pembelajaran, mengasah kemampuan siswa dalam menganalisis huruf hiragana yang pada permainan akan memunculkan beberapa kosakata-kosakata bahasa Jepang dalam bentuk huruf hiragana. Permainan bingo tidak hanya menekankan pada satu aspek saja melainkan melengkapi yang lainnya seperti, menulis, menyimak, membaca.

Hal ini juga didukung oleh penelitian terdahulu yang sudah pernah dilakukan oleh Widiantari (2016) tentang penerapan metode mnemonic berbantuan media "rensou kaado". Penelitian tersebut menunjukkan adanya peningkatan hasil belajar siswa terkait penguasaan huruf hiragana. Penelitian sejenis lainnya yang sudah pernah dilakukan oleh Wulandari (2017) tentang penerapan pembelejaran kooperatif yang dipadukan dengan permainan bingo. Penelitian tersebut menunjukkan peningkatan hasil belajar siswa dalam penguasaan huruf hiragana.

Berdasarkan latar belakang yang telah dipaparkan diatas, dapat ditarik rumusan masalah penelitian sebagai berikut. 1) Apakah penerapan model pembelajaran kooperatif berbantuan mnemonic dan permainan bingo dapat meningkatkan penguasaan huruf hiragana siswa kelas $X$ IBB 1 SMA N 1 Sukasada tahun ajaran 2018/2019? 2) Bagaimanakan respons siswa terhadap penerapan model pembelajaran kooperatif berbantuan mnemonic dan permainan bingo dapat meningkatkan penguasaan huruf hiragana siswa kelas X IBB 1 SMA N 1 Sukasada tahun ajaran 2018/2019?

\section{METODE PENELITIAN}

Penelitian tindakan kelas ini dilaksanakan di SMA Negeri 1 Sukasada tahun ajaran 2018/2019. Subjek yang digunakan pada penelitian ini adalah siswa kelas X IBB 1 dengan jumlah siswa secara keseluruhan sebanyak 24 orang. Sedangkan objek pada penelitian ini adalah penguasaan huruf hiragana.

Penelitian ini direncanakan sebanyak 2 siklus, tetapi tidak menutup kemungkinan untulk melanjutkan ke siklus selanjutnya sampai dinyatakan penelitian ini berhasil dan dapat memenuhi target sehingga penelitian ini dapat dihentikan. Pada setiap siklus akan dilakukan perencanaan penelitian, pelaksanaan tindakan, observasi/pengumpulan data, dan refleksi. Setiap akhir siklus, baik siklus I dan siklus II ditandai dengan adanya refleksi. Pada tahap refleksi akan dilakukan rencana perbaikan pada siklus selanjutnya agar kendala-kendala yang terjadi dapat teratasi dengan baik dan tidak terulang pada siklus selanjutnya. Berikut adalah bagan siklus penelitian yang digunakan pada penelitian ini. 


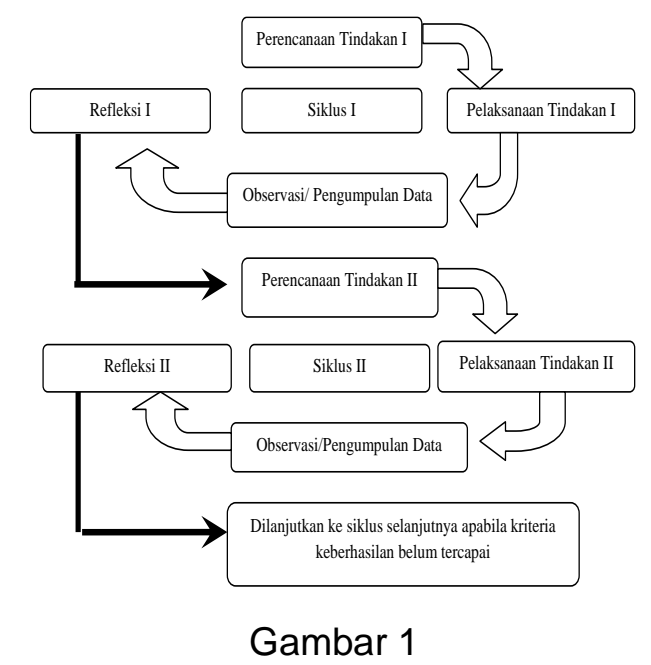

Rancangan Penelitian Tindakan Kelas

(Sumber: Arikunto, 2006:16)

Pada tahap perencanaan perlu adanya menyiapkan instrumen yang dibutuhkan seperti, menentukan jadwal kegiatan pebelajaran, membuat RPP dan silabus, membuat lembar kerja siswa, lembar observasi dan membuat lembar kuesioner serta memperiapkan diri hingga menyiapkan aturan permainan bingo. Kemudian pada tahap pelaksanaan sudah mulai menerapkan model pembelajaran kooperatif berbantuan mnemonic dan permainan bingo. Tahap observasi dilakukan ketika setelah menerapkan model pembelajaran kemudian menganalisis kondisi kelas. Tahap selanjutnya adalah refleksi pada tahapan ini segala aktifitas yang telah dilakukan di kelas kemudian mendaptkan hasil dan dianalisis. Jika terdapat siswa yang masih memeroleh nilai di bawah KKM dan belum mencapai kriteria keberhasilan maka perlu adanya perbaikan pada siklus selanjutnya.

Adapun rumus yang digunakan untuk menghitung nilai siswa adalah sebagai berikut.

$$
\mathrm{N}=\frac{S B}{T S} \times 100
$$

Penelitian ini menggunakan empat metode pengumpulan data yaitu metode observasi, metode tes, metode kuesioner dan wawancara. Data hasil observasi di analisis menggunakan pendekatan deskriptif kualitatif, sedangkan hasil tes serta kuesioner di analisis menggunakan pendekatan deskriptif kuantitatif.

\section{HASIL DAN PEMBAHASAN}

Sebelum melakukan penelitian, telah dilakukan wawancara kepada guru pengampu mata pelajaran bahasa Jepang. Hasil wawancara kepada guru menyatakan bahwa siswa kelas $X$ IBB 1 masih mengalami kendala dalam menulis huruf hiragana. Tahap awal pada penelitian ini adalah melakukan observasi awal dan juga memberikan pre-test untuk mengetahui kondisi awal siswa sebelum diberikan perlakuan. Tujuan dari pemberian pre-test ini juga utuk mengetahui permasalahan yang dihadapi oleh siswa. Pre-test terkait penguasaan huruf hiragana dilaksanakan pada tanggal 12 oktober 2018 dengan jumlah soal sebanyak 20 butir. 10 soal mengubah dari huruf romaji kedalam huruf hiragana, dan 10 soal mengubah huruf hiragana kedalam huruf romaji. Waktu yang diberikan dalam mengerjakan pre-test adalah 45 menit. Dari hasil yang diperoleh, hanya 5 orang siswa yang mendapatkan nilai diatas kriteria ketuntasan minimal (KKM). Nilai rata-rata yang diperoleh oleh siswa sebesar 53,52 \% dengan ketuntasan klaksikal sebesar 20,83\%. 
Berdasarkan hasil pre-test yang sudah dilakukan kemudian dilanjutkan pada siklus I dengan menerapkan model pembelajaran kooperatif berbantuan mnemonic dan permainan bingo untuk meningkatkan penguasaan huruf hiragana. Pada masing-masing siklus dilakukan sebanyak 3 kali pertemuan dengan 2 kali pertemuan untuk menerapkan model pembelajaran kooperatif berbantuan mnemonic dan permainan bingo dan pertemuan ketiga dilakukan pemberian post-test dan kuesioner.

Pelaksanaan siklus I sesi pertama dilaksanakan pada hari Selasa, 9 April 2019 pada jam pelajaran 09.15-10.45 alokasi waktu 2x45 menit pelajaran. Kegiatan awal dimulai dengan mengucapkan salam dan mengkonfirmasi kehadiran siswa, kemudian melanjutkan materi huruf hiragana pada pertemuan pertama siklus I antusias siswa tidak terlalu semangat, konsetrasi siswa masih terpecah dengan hal-hal diluar dari pelajaran. Selanjutnya guru menyampaikan tujuan model pembelajaran kooperatif berbantuan mnemonic dan permainan bingo. Ketika guru menjelaskan tujuan serta model pembelajaran kooperatif berbantuan mnemonic dan permainan bingo, siswa sedikit bingung dan acuh dengan apa yang disampaikan oleh guru. Namun ada beberapa siswa yang masih mendengarkan dengan baik penjelasan dari guru. Ketika guru menjelaskan huruf hiragana siswa terlihat senang dan sangat antusias mengikuti pelajaran karena siswa merasa jarang dalam mengikuti pelajaran bahasa Jepang dengan menggunakan media PPT dan berbantuan mnemonic. Pada permainan bingo siswa sangat senang dan bersemangat mengikuti pembelajaran. Pada kegiatan penutup hanya beberapa siswa saja yang bertanya dan yang lainnya hanya menyimak saja.

Pada pertemuan kedua siklus I yang dilaksanakan pada tanggal 11 April 2019 pada jam pelajaran 09.15-10.15 alokasi waktu 60 menit pelajaran. Dimulai dari kegiatan awal seluruh siswa sudah mampu mengikuti pembelajaran dengan baik dimulai dari menyampaikan salam, mengkonfirmasi kembali kehadiran, menyimak apa yang disampaikan oleh guru, ketika guru menyampaikan tujuan pembelajaran pada pertemuan pertama siswa masih senang melakukan hal-hal diluar pembelajaran, namun ketika pada pertemuan kedua seluruh siswa menyimak dan memerhatikan dengan baik penjelasan guru. Kemudian pada kegiatan inti juga sudah berjalan baik siwa sudah mampu mendengarkan instruksi guru ketika membentuk kelompok agar tidak gaduh dan ketika permainan dimulai juga sudah mampu mengontrol suara yang dikeluarkan selebihnya sudah berlangsung dengan lancar. Kemudian pada kegiatan penutup ketika guru bertanya kepada siswa, pada pertemuan pertama beberapa siswa masih malu-malu untuk bertanya namun pada pertemuan selanjutnya siswa sudah mulai berani dalam menyampaikan argumentasinya. Kemudian seluruh siswa menyimpulkan dan menutup pembelajaran dengan mengucapkan salam bersama-sama.

Setelah tindakan pada siklus satu yang terdiri dari dua pertemuan telah dilaksanakan, kemudian pemberian post-test pada pertemuan terakhir di siklus I pada hari Selasa, 16 April 2019. Post-test diberikan guna mengukur kemampuan penguasaan huruf hiragana dengan menggunakan model pembelajaran kooperatif berbantuan mnemonic dan permainan bingo dalam setiap pembelajaran. Sebelum memberikan post-test guru memberikan waktu 5 menit kepada siswa untuk mengingat kembali materi huruf hiragana yang sudah dipelajari.

Hasil post-test I menunjukkan jumlah siswa yang mencapai KKM meningkat menjadi 19 orang dengan nilai rata-rata $75,91 \%$ dan ketuntasan klasikal sebesar $62,50 \%$. Dari hasil posttest I terdapat beberapa huruf yang menjadi kendala oleh siswa sehingga mendapatkan nilai dibawah KKM. Adapun huruf-huruf yang menjadi kendala adalah huruf さ、き、は、ほ、ぬ、 め. Maka dari itu sebagai hasil refleksi dari siklus I akan diperbaiki pada siklus II dengan lebih menekankan pengajaran huruf-huruf yang menjadi kendala.

Hasil dari pre-test dan post-test siklus pertama dilakukan oleh siswa kelas X IBB 1 SMA N 1 Sukasada setelah menerapkan model pembelajaran kooperatif berbantuan mnemonic dan permainan bingo mengalami peningkatan. Perbandingan hasil pre-test dan post-test siklus pertama disajikan pada gambar 4.1. 


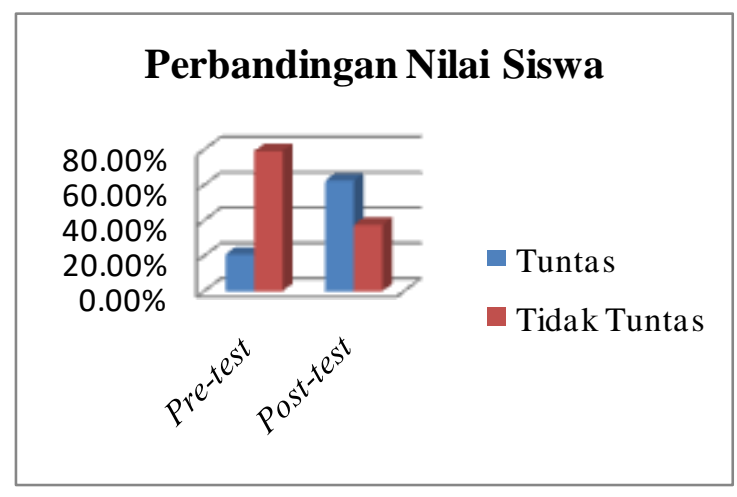

Gambar 4.1

Perbandingan Nilai Siswa

Pada gambar diagram 4.5 terlihat jelas peningkatan siswa yang mendaptkan nilai sesuai dengan KKM setelah diterapkannya model pembelajaran kooperatif berbantuan mnemonic dan permainan bingo dalam penguasaan huruf hiragana. Pada tahap pre-test terlihat $19(79,16 \%)$ siswa tidak tuntas dan $5(20,83 \%)$ siswa yang tuntas sedangkan pada tahap post-test siklus I terlihat $9(37,50 \%)$ siswa yang tidak tuntas dan 15 (62,50\%) siswa yang tuntas.

Hasil respons siswa pada siklus I menunjukkan hasil yang positif dengan jumlah respons sebesar 1053 dengan rata-rata 44. Pada kuesioner terbuka terdapat 3 buah pertanyaan yang akan diberikan kepada siswa dan menghasilkan jawaban. Berdasarkan hasil kuesioner yang sudah diberikan kepada siswa dapat dipaparkan hasil kuesioner terbuka dengan tiga pertanyaan yang telah diberikan kepada siswa kelas X IBB 1 SMA N 1 Sukasada tahun ajaran 2018/2019 yaitu pada pertanyaan pertama mengenai menurut pendapat anda apakah penerapan model pembelajaran kooperatif berbantuan mnemonic dan permainan bingo dapat membantu dalam menguasai huruf hiragana sebagaian besar siswa menjawa dapat melatih dalam menguasai huruf hiragana. Pada pertanyaan kedua kekurangan dari penggunaan model pembelajaran kooperatif berbantuan mnemonic dan permainan bingo dalam penguasaan huruf hiragana sebagian besar siswa menjawab terlalu rebut dan tidak seimbang dalam penilaian kelompok kemudian susah untuk dimengerti ketika huruf hiragana digambarkan sebagai bentuk nyata.

Pertanyaan terakhir kelebihan dari penggunaan model pembelajaran kooperatif berbantuan mnemonic dan permainan bingo dalam penguasaan huruf hiragana sebagian besar siswa menjawab lebih memotivasi dalam belajar bahasa Jepang khususnya huruf hiragana dan juga dapat mengingat lebih mudah huruf-huruf hiragana yang memiliki bentuk lebih kompleks.

Pada pelaksanaan siklus I terdapat suatu kendala yang menyebabkan diadakanya siklus II.Kendala yang dihadapi siswa keitika pelaksanaan siklus I yaitu. 1) Siswa masih belum bisa mengikuti pembelajaran dengan berbantuan teknik mnemonic sehingga pada pelaksanaan siklus II akan lebih ditegaskan kembali apa itu mnemonic serta memberikan contoh disekitar agar siswa lebih mudah mengikuti pembelajaran selanjutnya. 2) partisipasi siswa dalam mengikuti pembelajaran seperti ketika menuliskan kembali kosakata di papan sehingga pada pelaksanaan siklus II guru akan menunjuk secara acak siswa yang tidak fokus agar kembali fokus dan ikut berpartisipasi dalam keberlangsungannya pembelajaran. Sehingga tidak ada lagi siswa yang tidak memerhatikan guru ketika menuliskan kosakata di depan. 3) kurangnya waktu dalam pengisian lembar kerja permainan bingo dan pada pelaksanaan siklus II akan ditambahkan waktu untuk mengisi lembar permainan bingo.

Pelaksanaan tindakan pertama pada siklus II dialksanakan Kamis, 9 Mei 2019 pada jam pelajaran 12.30-13.50 alokasi waktu 2x45 menit pelajaran. Kegiatan pembelajaran pada pertemuan pertama siklus II dapat dikatakan sudah berjalan dengan lancar pada kegiatan awal siswa sangat antusias sebelum mengikuti pembelajaran inti dengan mengucapkan salam dan mengonfirmasi kehadiran. Pada pertemuan pertama juga tidak ada siswa yang absen.

Pada kegiatan inti seluruh siswa sudah mampu mengikuti pembelajaran dengan baik jika dilihat dari kemauan belajar siswa dalam memerhatikan penjelasan guru dan seluruh siswa 
juga sudah paham tentang penggunaan model pembelajaran kooperatif berbantuan mnemonic dan permainan bingo. Siswa juga sangat aktif jika guru menunjuk untuk maju mengerjakan kosakata bahasa Jepang. Pada kegiatan penutup juga siswa mau berpartisipasi dan bersamasama menyimpulkan pembelajaran hari itu. Jika dibandingkan dari pertemuan sebelumnya di siklus I sudah mengalami banyak perubahan yang dilakukan oleh siswa kelas X IBB 1 SMA N 1 Sukasada.

Pertemua kedua pada siklus II dilaksanakan pada hari pada kegiatan awal siswa sangat antusias sebelum mengikuti pembelajaran inti dengan mengucapkan salam dan mengonfirmasi kehadiran. Pada pertemuan pertama juga tidak ada siswa yang absen.

Pada kegiatan inti seluruh siswa sudah mampu mengikuti pembelajaran dengan baik jika dilihat dari kemauan belajar siswa dalam memerhatikan penjelasan guru dan seluruh siswa juga sudah paham tentang penggunaan model pembelajaran kooperatif berbantuan mnemonic dan permainan bingo. Siswa juga sangat aktif jika guru menunjuk untuk maju mengerjakan kosakata bahasa Jepang. Pada kegiatan penutup juga siswa mau berpartisipasi dan bersamasama menyimpulkan pembelajaran hari itu. Jika dibandingkan dari pertemuan sebelumnya di siklus I sudah mengalami banyak perubahan yang dilakukan oleh siswa kelas X IBB 1 SMA N 1 Sukasada.

Setelah tindakan pada siklus II yang terdiri dari dua pertemuan telah dilaksanakan, kemudian pemberian post-test pada pertemuan terakhir di siklus II pada hari Kamis, 16 Mei 2019. Post-test diberikan guna mengukur kemampuan penguasaan huruf hiragana dengan menggunakan model pembelajaran kooperatif berbantuan mnemonic dan permainan bingo dalam setiap pembelajaran.Soal terdiri dari materi yang sudah diajarkan ketika pertemuan pertama dan kedua pada siklus II. Jumlah soal terdiri dari dua romawi masing-masing romawi terdiri dari 10 kosakata. Sebelum memberikan post-test guru memberikan waktu 5 menit kepada siswa untuk mengingat kembali materi huruf hiragana yang sudah dipelajari.

Berdasarkan hasil post-test siklus II yang telah dilaksanakan, diperoleh hasil bahwa siswa yang tuntas sebanyak 24 orang (100\%). Pada hasil post-test siklus II tidak ada siswa yang mendapatkan nilai dibawah KKM (0\%). Dari hasil pre-test, post-test I dan post-test II telah terjadi peningkatan dalam penerapan model pembelajaran kooperatif berbantuan mnemonic dan permainan bingo. Perbandingan hasil pre-test, post-test I dan post-test II akan disajikan dalam gambar 4.2 .

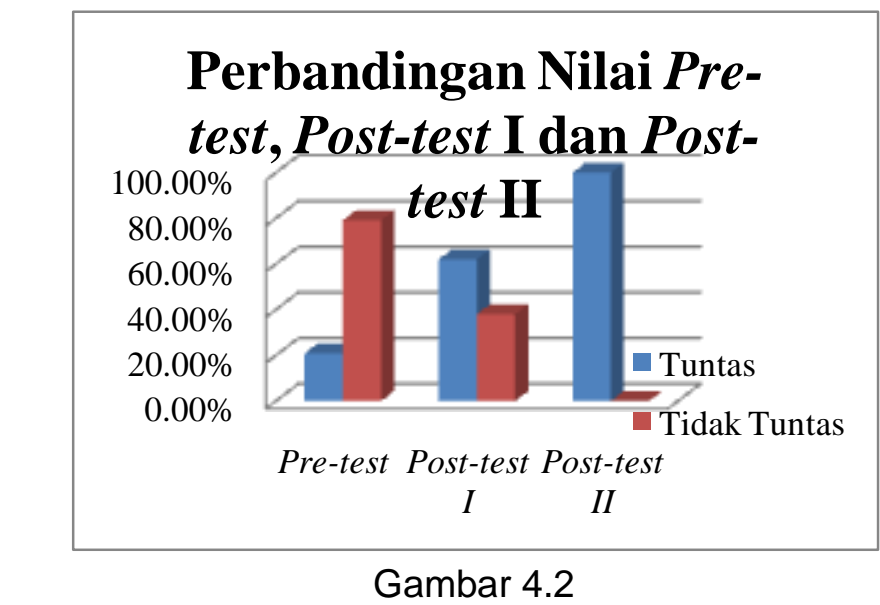

Perbandingan Nilai Pre-test, Post-test I dan Post-test II

Berdasarkan hasil perbandingan nilai pre-test, post-test I dan post-test II dapat dipaparkan sebagai berikut. Ketuntasan nilai pre-test pada KKM yang telah ditentukan hanya $20,83 \%$, pada post-test I mengalami peningkatan menjadi $62,50 \%$ dan pada post-test II juga mengalami peningkatan menjadi $100 \%$. Dari pemaparan tersebut dapat disimpulkan bahwa penerapan 
model pembelajaran kooperatif berbantuan mnemonic dan permainan bingo dapat meningkatkan penguasaan huruf hiragana siswa kelas X IBB 1 SMA $N 1$ Sukasada.Hal tersebut terlihat pada peningkatan nilai yang diperoleh oleh siswa X IBB 1 dalam penguasaan huruf hiragana.

Hasil kuesioner tertutup pada siklus II menyatakan bahwa respons siwa sangat positif terhadap penerapan model pembelajaran kooperatif berbantuan mnemonic dan permainan bingo. Dilihat dari jumlah respons pada siklus II sebesar 1099 dengan rata-rata 46. Pada hasil kuesioner terbuka terdapat 3 buah pertanyaan dari masing-masing pertanyaan memberikan respons yang positif. Pertanyaan pertama pendapat anda apakah penerapan model pembelajaran kooperatif berbantuan mnemonic dan permainan bingo dapat membantu dalam menguasai huruf hiragana sebagaian besar siswa menjawab sangat membantu dalam mengingat huruf hiragana, dapat memudahkan memahami dan menghafal huruf hiragana. Pertanyaan kedua apakah kekurangan dari penggunaan model pembelajaran kooperatif berbantuan mnemonic dan permainan bingo dalam penguasaan huruf hiragana sebagaian besar siswa menjawab penggunaan teknik mnemonic terlalu monoton dan tidak bervariasi dalam pembelajaran. Pertanyaan yang ketiga kelebihan dari penggunaan model pembelajaran kooperatif berbantuan mnemonic dan permainan bingo dalam penguasaan huruf hiragana sebagian besar siswa menjawab membantu lebih cepat paham dengan permainan bingo.

Peningkatan hasil belajar siswa dari siklus I dan siklus II menunjukkan grafik yang dikarenakan proses pembelajaran dengan menerapkan model pembelajaran kooperatif berbantuan mnemonic dan permainan bingo sudah berlangsung sesuai dengan prosedur yang direncanakan. Serta perbaikan-perbaikan yang dialami pada siklus I sudah dapat diatasi pada pelaksanan siklus II seperti menekankan dan mengajarkan kembali huruf-huruf yang menjadi kendala siswa, kemudian proses pengelolaan waktu di kelas sudah dapat diatasi sehingga tidak terulang kembali kejadian seperti pelaksanaan siklus I. Dari hasil analisis post-test II kendala siswa dalam menulis huruf hiragana sudah dapat teratasi seluruh siswa sudah mampu membedakan huruf-huruf yang menjadi kendala ketika proses pelaksanaan siklus I berlangsung.

Dari pemaparan tersebut dapat dinyatakan bahwa pelaksanaan siklus II telah mencapai kriteria keberhasilan $75 \%$ sehingga penelitian ini dapat dihentikan serta penerapan model pembelajaran kooperatif berbantuan mnemonic dan permainan bingo dapat dikatakan berhasiluntuk meningkatkan penguasaan huruf hiragana siswa kelas X IBB 1 SMA $N 1$ Sukasada Tahun Ajaran 2018/2019.

Penerapan model pembelajaran kooperatif berbantuan mnemonic dan permaianan bingo dapat meningkatkan penguasaan huruf hiragana siswa kelas X IBB1 SMA N 1 Sukasada tahun ajaran 2018/2019 karena dengan penerapan model pembelajaran kooperatif siswa menjadi lebih sering bertatap muka dengan teman dan menjadi lebih bertanggung jawab dan lebih percaya diri. Pada proses pembelajaran huruf hiragana siswa menjadi lebih mudah untuk mengingat bentuk huruf dengan berbantuan teknik mnemonic. Siswa juga sangat antusias ketika belajar huruf hiragana menggunakan teknik mnemonic. Dari yang awalnya siswa tidak senang belajar huruf hiragana sampai siswa menjadi senang belajar huruf hiragana. Dari penerapan model pembelajaran kooperatif berbantuan mnemonic dan permainan bingo memeroleh ketuntasan klasikal hingga 100\%.

Hasil kuesioner siswa terhadap penerapan model pembelajaran kooperatif berbantuan mnemonic dan permainan bingo untuk penguasaan huruf hiragana mendapatkan respons yang positif. Implikasi dari penerapan model pembelajaran kooperatif berbantuan mnemonic dan permainan bingo mampu meningkatkan hasil belajar siswa khususnya pada penguasaan huruf hiragana. Hal ini dibuktikan dengan siswa memahami betul materi yang disampaikan dan dapat dengan mudah mengingat huruf hiragana ketika dalam mengikuti pembelajaran di kelas. Ingatan siswa terhadap huruf hiragana sangat kuat karena penggunaan teknik mnemonic yang memudahkan siswa untuk lebih kuat dalam mengingat huruf hiragana. Selain itu siswa sangat aktif mengikuti pembelajaran dengan berkelompok baik itu belajar maupun pada saat melakukan permainan bingo. 
Respons siswa terhadap penerapan model pembelajaran kooperatif berbantuan mnemonic dan permainan bingo dapat digolongkan positif. Hal ini dilihat dari keaktifan siswa dalam setiap mengikuti pembelajaran di kelas, kemudian siswa sangat antusias dalam menyimak materi dan ketika siswa mengikuti permainan bingo antusias siswa sangat luar biasa. Dalam mengikuti proses pembelajaran siswa merasa wawasan terhadap bahasa jepang khususnya pada huruf hiragana meningkat dan siswa senang karena lebih mengerti, memahami dan menulis huruf hiragana dan termotivasi dalam mengikuti pembelajaran selanjutnya.

\section{SIMPULAN DAN SARAN}

Berdasarkan analisis terhadap data hasil penelitian tindakan kelas (PTK) pada siswa kelas $X$ IBB 1 SMA N 1 Sukasada dengan penerapan model pembelajaran kooperatif berbantuan mnemonic dan permainan bingo, dapat ditarik kesimpulan sebagai berikut. 1) penerapan model pembelajaran kooperatif berbantuan mnemonic dan permainan bingo dapat dikatakan meningkatkan penguasaan huruf hiragana siswa kelas X IBB 1 SMA N 1 Sukasada. Hal ini dibuktikan dari hasil pre-test memeroleh ketuntasan klasikal mencapai 20,83\%. Kemudian pada siklus I mengalami peningkatan dengan ketuntasan klasikal sebesar $62,50 \%$. Pada siklus II terjadi peningkatan yang signifikan yaitu dengan ketuntasan klasikal sebesar $100 \%$. Hal tersebut membuktikan bahwa peningkatan hasil belajar siswa kelas $X$ IBB 1 SMA $N 1$ Sukasada disebabkan karena penerapan model pembelajaran kooperatif berbantuan mnemonic dan permainan bingo.

Berdasarkan hasil analisis kuesioner, respons siswa terhadap penerapan model pembelajaran kooperatif berbantuan mnemonic dan permainan bingo dinyatakan tergolong positif. Hal ini dibuktikan dari hasil kuesioner tertutup pada siklus I dan siklus II memeroleh ratarata 44 dan 46 yang artinya tergolong positif. Tidak hanya pada kuesioner tertutup saja yang membuktikan hasil positif, pada kuesioner terbuka juga menyatakan bahwa penerapan model pembelajaran kooperatif berbantuan mnemonic dan permainan bingo sangat membantu dalam mengingat huruf hiragana, mampu membuat lebih mengerti dalam belajar bahasa Jepang.

Saran dari penelitian ini diharapkan dapat member motivasi bagi guru tentang bagaimana menerapkan model pembelajaran yang tepat sesuai dengan karakteristik siswa di kelas dan dapat mengetahui sejauh mana siswa memahami materi yang akan diajarkan. Hasil penelitian ini dapat digunakan bagi peneliti lain yang hendak melakukan penelitian pada permasalahan yang berbeda misalkan pada aspek yang berbeda, namun dengan tetap memerhatikan kendala-kendala yang terjadi pada penelitian ini agar pada penelitian selanjutnya dapat diperbaiki dan disempurnakan, serta hasil penelitian ini dapat menambah ilmu pengetahuan.

\section{DAFTAR RUJUKAN}

Anari, Farzaneh K, dkk. 2015. The Magic of Mnemonics for Vocabulary Learning of a Second Language. International Journal of Language and Linguistics. Vol. 3, No. 1-1, ISSN: 2330-0205.

Tersedia pada http://article.sciencepublishinggroup.com/pdf/10.11648.j.jill.s.2015030101.11.pdf

Arikunto, Suharsimi. 2006. Penelitian Tindakan Kelas. Jakarta: BumiAskara.

Novita, R Yulaekha. 2016. Efektivitas Permainan Bingo Dalam Pembelajaran Program Aplikasi Kelas VII SMP Negeri 25 Purworejo. Skripsi. Universitas Negeri Semarang.

Suprijono, Agus. 2009. Cooperative Learning, Teori \& Aplikasi PAIKEM. Surabaya: Pustaka Pelajar.

Trianto. 2010. Model Pembelajaran Terpadu Konsep, Strategi, Dan Implementasinya Dalam Kurikulum Tingkat Satuan Pendidikan (KTSP). Jakarta: Bumi Aksara. 
Widiantari, Ni Wayan, Yogi, dkk. 2016. Penerapan Metode Mnemonic Berbantuan Media Kartu "Rensou Kaado" Untuk Meningkatkan Penguasaan Huruf Hiragana Siswa Kelas X Upwc Smk Negeri 1 Singaraja Tahun Ajaran 2015/2016. Skripsi. Jurusan Pendidikan Bahasa Jepang. Fakultas Bahasa dan Seni. Universitas Pendidikan Ganesha.Tersedia pada https://ejournal.undiksha.ac.id/index.php/JJPBJ/article/view/7842

Wulandari, Dian, Komang, dkk. 2017. Penerapan Model Pembelajaran Kooperatif yang Dipadukan Dengan Permainan Bingo Untuk Meningkatkan Kemampuan Penguasaan Huruf Hiragana Kelas XI IPA 5 SMA N 1 Selemadeg Tahun Ajaran 2017/2018. Skripsi. Jurusan Pendidikan Bahasa Jepang. Fakulas Bahasa dan Seni. Universitas Pendidikan

Ganesha.Tersedia Pada https://ejournal.undiksha.ac.id/index.php/JJPBJ/article/view/12386 